\title{
RECENZIÓ DÖRNYEI KRISZTINA RITA CSOMAGOLÁSMENEDZSMENT CÍMŰ KÖNYVÉHEZ
}

$\mathrm{A}$ z általános közvélekedés szerint a csomagolás egyszerüen csak valami "zacskó", nem több. De miért tanulják meg ilyen lassan a vezetéssel foglalkozó szakemberek, hogy a termék és ellátási lánc olyan részeleme, amely nélkülözhetetlen a sikerhez? Ekkor gondolkodtam el, hogy itt az ideje elolvasni Dörnyei Krisztina Rita a menedzsmenttel foglalkozó szakemberek számára nélkülözhetetlen müvét, a Csomagolásmenedzsmentet (Kossuth Kiadó, 2019).

A témakör aktualitását jelzi, hogy a csomagolás értékteremtés témaköre közel 30 éve tört be a menedzsmenttel és marketinggel foglalkozó nemzetközi akadémiai kutatásokba és az operatív vonatkozású ipari gyakorlatba. Ez nem meglepő, hiszen a csomagolás potenciálisan a vevőérték egyik meghatározó forrása az értékláncban. A nemzetközi szakirodalomban újabb és újabb akadémiai szakcikkek mellett üzleti fókuszú könyvek is folyamatosan megjelentek e témakörben. Ugyanakkor a magyarországi szakirodalomban gyakorlatilag ez a témakör átfogóan feldolgozatlan maradt. A magyarországi felsőoktatásban is csak a kizárólag müszaki-tervezői szempontú, vagy müszaki-gyártási relevanciájú szakterületek speciális igényű szakkönyvei jelentek meg ezidáig.

Pedig közismert, hogy a csomagolás számos olyan szakterülettel kerül nap mint nap kapcsolatba, mint a vállalati marketing, logisztika vagy terméktervezés. Mégis a szakkönyvek jelentős része még csak említés szintjén is ritkán foglalkozik vele, nem is beszélve a felsőoktatási tananyagokról, amelyek idehaza gyakorlatilag teljesen nélkülözik az átfogó és rendszerszemléletü oktatást a csomagolás területén. Miközben vitathatatlan, hogy kiemelkedő szerepe van az értékteremtés és értékesítés folyamatában. A fentiek átfogó bemutatására és elemzésére vállalkozott a könyv szerzője. Nem kis feladat!

\section{Menedzsment}

A könyv részletesen foglalkozik mindazon tevékenységgel, amely a csomagolás funkcióját és célját definiálják, és részletesen tárgyalja a csomagolás kialakításához és fejlesztéséhez vezető folyamatokat, továbbá miként válik menedzsmentfeladattá a csomagolás mint vállalati eszköz. Meg kell jegyezni, hogy a könyv elsősorban a fogyasztói csomagolást és annak szerepét tárgyalja, és úgy szentel neki kiemelt szerepet a marketingben, hogy megfelelő összhangot teremt az egyes csomagolással foglalkozó részte- rületek között.

A könyv kimondott célja, hogy felhívja a menedzsment érdeklődését az aránytalanul kevés figyelmet mutató csomagolási témakör iránt. Ennek érdekében a szerző nemcsak bemutatja a csomagolást, hanem pontosan azonosítja és elmagyarázza a modern gazdaságban a csomagolás betölteni kívánt szerepét. Hiszen a csomagolás a megfelelö alapanyagforrástól egészen az otthonunkig jelen van, bejárva a vállalat minden részterületét, értékesítési csatornáját és reklámtevékenységét. Részletesen elemzi a csomagolás kapcsolódási pontjait a területekkel, hogy miként válik részévé a brand-nek, milyen jelentőséget kölcsönöz a termékpolitikának, és nem utolsó sorban miként egészíti ki a vállalati kommunikációt a kereskedelmi és értékesítési végpontokon.

Dörnyei Krisztina könyve nem ódzkodik a legnehezebb feladatoknak is nekifutni. Hogyan válik a csomagolás értékteremtő folyamattá, egészíti a "core competence" tevékenységet. Részletes ismeretek ad a menedzsereknek egészen az ötlet felmerülésétől a piacra kerülési folyamatig, úgy mint a grafika, a szín, a forma, a megjelenés, az elhelyezés és dizájn fontosságáról, ezek szinergikus öszszességéről.

\section{Akadémia és az elméleten túl}

A könyv széles körben elemzi és használja fel a nemzetközi szakirodalmat. A közel 300 referencia jelentős része magasan rangsorolt, többször bírált tudományos folyóiratok elméleti és gyakorlati kutatásainak eredményeit szintetizálja (nem utolsó sorban az elmúlt tíz év során megjelent rendkívül friss kutatási eredmény felhasználásával). A szerző jártasságát igazolja, hogy saját, ugyancsak többször bírált kutatási eredményeit is felhasználta a könyv elkészítése során. Az akadémiai szakcikkek mellett a témát érintő üzleti könyvek is szép számmal felbukkannak a könyvben. A szerző az egyes témakörökre bontott fejezetek során (kiemelkedő, hogy példás alapossággal) számos magyarországi vonatkozású gyakorlati példán keresztül is bemutatja, hogy a könyvben szereplő ismeretek hogyan implementálhatók a gyakorlatban, miként szolgálják a vállati célokat és az elmélet megvalósíthatóságát.

Külön meg kell jegyezni, hogy a könyvben megfogalmazott tudást rendkívüli haszonnal forgathatják nemcsak a menedzsment-szakemberek, de interdiszciplinaritásából fakadóan a teljes értéklánc minden szereplője, hiszen egy 
sor ismert, de idehaza csak felületesen, vagy javarészt érintőlegesen megfogalmazott tudás mélységét ismerhetik meg a csomagolás szerepe és célja kapcsán, ezáltal a saját értékláncuk és a termékek versenyelőnyét őrizhetik meg, vagy éppen biztosíthatják. Mindezt egy rendkívül esztéti- kus és jól átgondoltan szerkesztett könyvben találja meg a kedves olvasó.

A csomagolás által biztosítható versenyelőny és értékteremtés jobbá tételéhez kapcsolódik és járulhat hozzá Dörnyei Krisztina Rita új könyve. 